A ne ta Ka m ińs ka ORCID: 0000-0002-4612-6464

Akademia Ignatianum w Krakowie

\title{
Dialog w polskich placówkach szkolnych - istotny problem edukacii i pedagogiki (na podstawie badań własnych)
}

Dialogue in Polish Schools: An Important Problem of Education and Pedagogy (Based on the Author's Own Research)

\begin{abstract}
ABSTRAKT
Przedmiotem niniejszego opracowania jest dialog w szkole. Celem teoretycznym jest ukazanie dialogu $w$ szkole na bazie literatury przedmiotu, a celem praktycznym ukazanie, jak osoby, które w przyszłości będa pełniły (a niektóre już pełniq) funkcję dyrektorów szkół, postrzegają istotę dialogu. Posłużono się strategia badań jakościowych, natomiast metodq była dyskusja grupowa. Jeżeli chodzi - grupę badawczq, to respondenci zostali dobrani losowo wśród słuchaczy studiów podyplomowych, na kierunku oświata i zarzqdzanie w oświacie w Akademii Ignatianum w Krakowie. Byli to obecni oraz potencjalni dyrektorzy szkół. W ramach niniejszego artykułu została przedstawiona istota dialogu i współczesne jego zagrożenia wynikające $z$ warunków obecnego życia. Autorka dokonała próby charakterystyki współczesnej polskiej szkoły w kontekście podejmowania
\end{abstract}

StOWA KLUCZOWE dialog, dialog w szkole, współczesne zagrożenia dialogu, istota dialogu, korzyści płynqce $z$ dialogu

\section{KEYWORDS}

dialogue, dialogue at school, contemporary threats to dialogue, the essence of dialogue, benefits of dialogue

SPI Vol. 22, 2019/1

ISSN 2450-5358

e-ISSN 2450-5366

DOI: 10.12775/SPI.2019.1.007

Nadesłano: 30.10 .2018 Zaakceptowano: 18.03.2019

Raporty z badań 
dialogu. Artykuł zawiera także przedstawienie analizy i wniosków badań własnych, w tym szeroko przedstawionych wniosków do dalszej praktyki edukacyinej. Należq tu przede wszystkim sugestie: ciqgłego podnoszenia kompetencji komunikacyjnych wśród nauczycieli i pozostałych podmiotów życia szkoły; poznawania własnych emocji i postaw, które warunkuja dialog oraz pracę nad nimi; zwrócenia baczniejszej uwagi na korzyści z dialogu w ramach placówek edukacyjnych przez wypracowanie odpowiednich strategii w celu ulepszania i podtrzymywania dialogu: organizacji bezpłatnych warsztatów dialogu na terenie kraju w celu podnoszenia kultury dialogu narodu polskiego; wzięcia pod uwagę konieczność dostosowania dialogu do rozmówcy, w tym do osób z obcych krajów.

\section{ABSTRACT}

The subject of this study is dialogue at school. The theoretical aim is to show dialogue at school on the basis of literature on the subject, and the practical goal is to show how current and future school directors perceive the essence of dialogue. The qualitative research strategy was used, with the choice of method being the group interview. In terms of the research group, the respondents were chosen randomly from among postgraduate students, in the field of education and management in the Jesuit University of Philosophy and Education Ignatianum in Krakow. These included current and potentially future school headmasters. As part of this article, the essence of dialogue and contemporary threats resulting from the conditions of modern life are presented. The author attempts to characterize the contemporary Polish compulsory school in the context of undertaking a dialogue. This article also presents the analysis and conclusions of their own research, including conclusions for further educational practice. These include the following suggestions: continuous improvement of communication skills among teachers and other subjects of school life; learning about our own emotions and attitudes that condition dialogue and work on them; pay closer attention to the benefits of dialogue within educational institutions - developing appropriate strategies and adopting philosophies/discourses in order to improve and maintain dialogue; organization of free dialogue workshops throughout the country in order to increase the culture of dialogue of the Polish nation; taking into account the need to adapt the dialogue to the interlocutor, including people from foreign countries. 


\section{Wprowadzenie}

Wielość publikacji artykułowych i książkowych na temat dialogu, w tym prowadzonego w szkole, świadczy o ciągłej aktualności i żywotności tego tematu. Większość naukowców z dziedziny psychologii i pedagogiki nawołuje do podejmowania dialogu nauczycieli z uczniami, przede wszystkim we wczesnym wieku szkolnym, gdyż zdają sobie doskonale sprawę, jak ważne są pierwsze doświadczenia relacji komunikacyjnych. Warunkują one umiejętność podejmowania dialogu w późniejszym życiu. Jednakże nie tylko we wczesnym wieku jest on ważny. Powszechnie wiadomo, jak niejednokrotnie trudno dojść do porozumienia w relacji adolescent-dorosły, gdy do głosu u młodego człowieka dochodzi jego własny sposób widzenia świata, często bardzo odmienny od tego, który prezentują starsze pokolenia. Dialog jest też ważny w dojrzałym wieku. Liczba przeżytych lat nie czyni od razu człowieka wykwalifikowanym mówcą i dobrym słuchaczem. Dialog wymaga pewnego wysiłku, uczenia się go i ciąłłego podejmowania, nawet mimo pewnych porażek na tym polu.

Dialog w szkole jest tematem niezwykle szerokim, niemożliwym do wyczerpania w ramach niniejszego artykułu. Namysłu nad nim dokonują specjaliści, m.in. znany ze swojej twórczości o dialogu Marian Śnieżyński w dziełach pt. Zarys dydaktyki i dialogu oraz Dia$\log$ edukacyjny ${ }^{2}$, jest też przedmiotem codziennych rozmów, także w gronie rodzinnym. Jednakże czy to oznacza, że my, ludzie, jesteśmy biegli w podejmowaniu dialogu? Zdaniem autorki tak nie jest. $\mathrm{Na}$ wiązujemy do dialogu, gdyż jednostkowo i społecznie odczuwamy brak jego efektywności i satysfakcji z jego podejmowania. Ponadto, bezpośredniego dialogu nie ułatwia możliwość korzystania z nowinek technologicznych, za którymi często niejako „chowamy się”. Niejednokrotnie można zauważyć zwłaszcza młodych ludzi siedzących obok siebie z telefonami w rękach, którzy ze sobą nie rozmawiają. Natomiast w domach dialog przy stole bywa zagłuszany przez telewizor i komputer.

1 M. Śnieżyński, Zarys dydaktyki i dialogu, Kraków 1998.

2 M. Śnieżyński, Dialog edukacyjny. Teoretyczne zatożenia a szkolna rzeczywistośc, Kraków 2005. 
W szkole dialog zaburzony jest hierarchicznością relacji nauczyciel-uczeń, gdy ten, wymieniony jako drugi, jest zawsze na pozycji podporząakowania. Nadal mniejszość nauczycieli realizuje ideę partnerstwa w dialogu z uczniami. Dla niektórych stosowanie takiego konceptu jest niewłaściwe, niewyobrażalne i w efekcie szkodliwe. Relacji tej nie ułatwia fakt konieczności wystawiania uczniom ocen w szkole, co niejednokrotnie skutkuje uczniowskim stresem, fobiami szkolnymi i brakiem zaufania do nauczycieli. Niestety nikt jeszcze nie wymyślił dla publicznej, polskiej szkoły innego systemu weryfikacji, jak oceny, których idea jest zakorzeniona w dyskursie behawioralnym. $Z$ drugiej strony, ich brak mógłby powodować w szkole chaos. Rodzi się zatem pytanie, jak oceniać uczniów, żeby nie zaburzać relacji z nimi.

Ponadto, „bezgłośnym językiem” jest także wystrój szkoły. Można zastanowić się, co komunikują dobrze wyposażone, kolorowe, parterowe fińskie szkoły, z kanapami do odpoczynku i możliwością chodzenia bez butów, jak w domu, a co niektóre polskie i francuskie duże, szare szkoły, tzw. „molochy”, gdzie w klasach nie znajdziemy m.in. obrazków dziecięcych. Poprzez wystrój wnętrz wiele komunikujemy uczniom.

Wreszcie dialog nauczyciel-rodzice/rodzice-nauczyciel to prawdopodobnie, co wynika $\mathrm{z}$ licznych badań w Polsce, jedna z najtrudniejszych form dialogu między podmiotami zaangażowanymi w życie szkoły. Czy ogranicza się on ze strony nauczycieli do podania ocen oraz informacji na temat osiągnięć i braków uczniów, czy też ma bardziej „ludzki wymiar”?

Marian Śnieżyński podkreśla znaczenie dialogu w szkole, twierdząc, że „potrzeba przygotowania uczniów do dialogu staje się niezbywalną koniecznością związaną nierozerwalnie z procesem kształcenia dzieci i młodzieży. Nauka negocjowania, stawiania pytań, kultury dyskusji, obrony swoich racji, szanowania poglądów drugiej osoby, może z powodzeniem procentować w życiu dorosłym”3.

Te i wiele innych pytań dotyczących dialogu w polskiej szkole obowiązkowej zainspirowały autorkę do namysłu nad tą kwestią. Szczególnie interesujące jest, jakie pomysły i plany na usprawnienie dialogu w ich placówkach szkolnych mają przyszli dyrektorzy.

3 Tamże, s. 2. 


\section{Istota dialogu i współczesne jego zagrożenia}

Obecnie zadaniem nauczyciela nie jest już, jak niegdyś, arbitralne orzekanie o słuszności czegokolwiek, czy bycie w sytuacji pedagogicznej instancją wyższą, gdyż w kontekście zachodzących w świecie zmian nie ma to wyraźnego sensu. Nauczyciel przestał być wyłącznie przekaźnikiem transmitującym wiedzę, do której bez trudu można dziś dotrzeć samodzielnie. Rola pedagoga polega na byciu przewodnikiem w świecie nauki i kultury, i to wobec ucznia, który tego potrzebuje. Nauczyciel jest interpretatorem, tłumaczem otaczającej rzeczywistości kulturowej, nie prawodawcą. Może proponować, nie zaś narzucać. Dlatego też każdy, kto chce stać się dla swoich wychowanków znaczący, powinien posiadać umiejętność wchodzenia z nimi $\mathrm{w}$ interakcję w procesie bezpośredniej, dwukierunkowej komunikacji ${ }^{4}$ - ,jej szczególną formą jest dialog, który zachodzi wówczas, gdy odbiorca staje się nadawcą i odbiorcą jednocześnie"5.

Należy sobie uświadomić, że to właśnie dialog jest podstawowym narzędziem procesu edukacyjnego i szansą dla rozwoju zarówno nauczyciela, jak i ucznia. Jego warunkiem jest prawdziwość, słuszność, szczerość oraz intencja osiąnnięcia porozumienia. Ponadto $\mathrm{w}$ autentycznym dialogu każdy ma prawo do krytykowania wypowiedzi rozmówcy oraz odpierania argumentów cudzej krytyki - podmioty w dialogu mają równy status ${ }^{6}$.

Wskazana byłaby otwartość nauczycieli na dialog z uczniami. Wiąże się ona $\mathrm{z}$ umiejętnością dzielenia się z nimi tym, co czuje się wobec nich, wobec tego, co zrobił lub powiedział uczeń. Zatem otwartość nie jest ujawnianiem intymnych szczegółów z przeszłości, ale odkrywaniem reakcji na zdarzenia wspólnie doświadczane i tylko w koniecznych sytuacjach wyjaśniane w kontekście dotychczasowych przeżyć. Otwartość powinna być odpowiednia do charakteru relacji

4 A. Matusz-Rżewska, Nauczyciel-uczeñ. O paradoksach wzajemnej komunikacji, w: Ucztowieczyć komunikacje. Nauczyciel wobec ucznia w przestrzeni szkolnej, red. H. Kwiatkowska, Kraków 2015, s. 462.

5 M. Chodorowska-Chromiec, Kompetencje komunikacyjne nauczyciela w pracy z uczniem, w: Nauczyciel kompetentny, Teraźniejszość i przysztość, red. Z. Bartkowicz, M. Kowalczuk, M. Samujło, Lublin 2007, s. 111.

6 Por. J. Habermas, Teoria dziatania komunikacyjnego, Racjonalnośc dziatania a racjonalność spoteczna, t. 1, przeł. A.M. Kaniowski, Warszawa 1999, s. 159. 
z drugą osobą, być raczej stałą częścią tego, co dzieje się z ludźmi w danej chwili, a nie czymś przypadkowym. Musi być dwustronna i stwarzać możliwości umocnienia relacji. Należy mieć na uwadze jej ewentualne skutki dla drugiej osoby. Musi zwiększać się w trudnych warunkach i z czasem sięgać coraz głębiej. Zbyt pochopna otwartość może zaburzyć relacje. Musi być budowana stopniowo ${ }^{7}$.

Dialog może być zaburzony $z$ wielu powodów, w tym ze strony jednostki, np. ze względów osobowościowych, związanych z nieodpowiednią postawą wobec innych, z powodu trudności psychicznych, intelektualnych, relacyjnych, niedojrzałości, aż w końcu niechęci do dialogu. Brak dialogu może być spowodowany także znacznymi różnicami kulturowymi, społecznymi jednostek, które nie są w stanie przejść poza barierę zwyczajów, obyczajów, języka itp. Jednostka może odczuwać opór w dialogu, który z kolei może być reakcją na nacisk, przemoc w procesie kształtowania wymagań wobec tej jednostki. Niejednokrotnie wynika on ze stosowania konserwatywnych zasad w relacji ${ }^{8}$. Paul Willis w przeprowadzonych badaniach etnograficznych dostrzegł celowe separowanie się pewnej grupy uczniów (dzieci robotników) od reszty szkoły. Spowodowane to było ich przekonaniem, że role, jakie w przyszłości podejmą, są całkiem rozbieżne z tymi, które oferuje im szkoła ${ }^{9}$.

W obecnej dobie szybkiego tempa życia i pokolenia „Ikea”, czyli takiego, które otrzymuje wszystko gotowe, trudniej jest pracować nad dialogiem, trudniej nawet o chęci do włożenia wysiłku w taką naukę, a rzeczywiście bywa ona wymagająca.

Piotr J. Śliwiński twierdzi, że człowiek ślizga się po rzeczywistości i skupia uwagę jedynie na silniejszych komunikatach, pozostając przy nich na krótko i ignorując te bardziej subtelne ${ }^{10}$. Szczególnie obserwujemy, jak trudno młodym ludziom skupić uwagę na

7 Por. M. Samujło, T. Sokołowska-Dzioba, Jezzyk otwartości w relacji nauczyciel-uczeń, w: Ucztowieczyć komunikacje. Nauczyciel wobec ucznia w przestrzeni szkolnej, Kraków 2015, s. 443.

8 Por. P.L. McLaren, Antystruktura oporu, w: Nieobecne dyskursy, cz. 2, Toruń 1992 , s. 36.

9 Por. W. Feinberg, J. Solis, Szkoła i społeczeństwo, przeł. K. Kruszewski, Warszawa 2000, s. 62.

10 Por. P.J. Śliwiński, Zagubiony i odnaleziony w nie-miejscu, w: Kondycja cztowieka wspótczesnego, red. C. Piecuch, Kraków 2006, s. 55. 
rozmowie $z$ drugim człowiekiem. Wydaje się, że nie potrafią oni ani słuchać, ani mówić w bezpośrednim kontakcie. Lepiej wychodzi im porozumiewanie się $\mathrm{z}$ innymi, a robią to głównie $\mathrm{z}$ rówieśnikami, nie $\mathrm{z}$ dorosłymi, poprzez komunikatory. Rozmawiają też wtedy z większą liczbą osób w sieci (robiąc także różne inne rzeczy, m.in. oglądając film - powszechna jest ich wielozadaniowość). Wiele razy można też zauważyć młodych ludzi siedzących obok siebie, nie rozmawiających, ale zatopionych w swoich telefonach komórkowych. Efektem są trudności również na egzaminach na uczelni. Studenci preferują egzaminy pisemne, gdyż wtedy mogą „ukryć” się za kartką papieru. Nie muszą wiedzieć, jak się zachować w bieżącej rozmowie. Nie biorą bezpośredniej odpowiedzialności za swoje słowa i nie muszą oglądać reakcji zwrotnej na nie. Jako nowoczesne społeczeństwa zagubiliśmy chęć i postrzeganie wartości w bezpośredniej, niespiesznej i autentycznej rozmowie $\mathrm{z}$ drugim człowiekiem, w tym dla przyjemności, a nie dla jednostkowych natychmiastowych korzyści.

Natomiast według Henryka Rettera do komunikacji systematycznie zniekształcanej dochodzi na przykład wtedy, gdy dobrowolna komunikacja ustępuje miejsca psychicznym strategiom obronnym, a partnerzy komunikacji ograniczają swe działanie do odgrywania roli sprawcy i ofiary. Komunikacja taka może być również wyrazem zakłóconej równowagi tożsamości, którą utrzymuje się z konieczności jej zabezpieczenia ${ }^{11}$.

\section{Próba charakterystyki współczesnej polskiej szkoły obowiazkowej w kontekście podejmowania dialogu}

Szkoły starają się sprostać wymaganiom stawianym im przez Ministerstwo Edukacji Narodowej, które są określone głównie w Ustawie z 14 grudnia 2016 r., rozdz. 1, art. 1, związanymi z dynamicznie zmieniającym się światem. Dotyczą one: opieki nad uczniami szczególnie uzdolnionymi, m.in. poprzez umożliwienie realizowania indywidualnych programów nauczania; kształtowanie u uczniów postaw przedsiębiorczości sprzyjających aktywnemu uczestnictwu w życiu

11 Por. H. Retter, Komunikacja codzienna w pedagogice, przel. M. Wojdak-Piątkowska, Gdańsk 2005, s. 59. 
gospodarczym kraju; przygotowywanie uczniów do wyboru zawodu i kierunku kształcenia oraz do rozwoju zainteresowań i uzdolnień przez organizowanie zajęć pozalekcyjnych i pozaszkolnych oraz kształtowanie aktywności społecznej i umiejętności spędzania czasu wolnego ${ }^{12}$. Ponadto, oprócz wyżej wymienionych, szkoła ma wiele innych standardowymi obowiązków, z którymi radzi sobie w różny sposób. Obecny kierunek polskiej edukacji w stronę jej decentralizacji od 1996 roku i większej autonomii szkół (ale też większej ich odpowiedzialności za funkcjonowanie) powoduje znaczne różnice w poszczególnych regionach kraju i w ramach poszczególnych szkół.

Jedni naukowcy twierdzą, że obecnie szkoła zmaga się z różnymi problemami, które przyczyniają się do jej w części negatywnego wizerunku. Jest miejscem, w którym są stosowane konserwatywne zasady relacji między nauczycielami a uczniami. Zdarza się, że wymaga się od uczniów postaw, których często nie potrafią przejawiać z powodu ich niezrozumienia. Także sami nauczyciele nie odczuwają więzi ze szkołą, są niepewni jutra, sfrustrowani i bierni ${ }^{13}$. Pewne trudności występują w samej organizacji szkoły, metodach nauczania, postawach nauczycieli i uczniów, ich wzajemnych relacjach, niedostatku materialnym oraz negatywnym wpływie grup rówieśniczych ${ }^{14}$. Taką sytuację potwierdzają m.in. badania Marii Dudzikowej i Renaty Wawrzyniak-Beszterdy z dzieła pt. Doświadczenia szkolne pierwszego rocznika reformy edukacji. Autorki przedstawiły wyniki badań uczniów, którzy twierdzili, że nie czuli się dobrze w swojej szkole, nie mieli zaufania do swoich nauczycieli i nie mogli wyrażać swoich poglądów ani wpływać na to, co dzieje się w szkole. Ponadto, uczniowie (badani byli zarówno gimnazjaliści, jak i licealiści) ukazują swoje zdziwienie, że nauczyciele wymagają od nich samodzielności w uczeniu się, co zdradza, jak bardzo są przywiązani do biernej postawy, do obrazu osoby, która tylko pamięciowo przyjmuje wiedzę i legitymuje

12 Ustawa o systemie oświaty z dnia 14 grudnia 2016 r., rozdz. 1, art. 1, pkt. 1, 3, 5, 8, 18, (Dz. U. 2017 poz. 59, art. 1.)

13 M. Michalicka-Ipnarska, Szkota, jakiej potrzebujemy, w: Ucztowieczyć komunikacje. Nauczyciel wobec ucznia w przestrzeni szkolnej, red. H. Kwiatkowska, Kraków 2015, s. 482.

14 Tamże, s. 483. 
się nią, gdy zachodzi taka potrzeba ${ }^{15}$. Takie osoby nie będą umiały także zadawać pytań i dokonywać krytycznej refleksji nad zagadnieniami teoretycznymi.

Inni upatrują w szkole miejsce, w którym odnajdują wzajemne zrozumienie, inspirację do nauczania i uczenia się, do rozwoju. Doświadczenia szkolne zależą od danej placówki, jak jest zarządzana, jaki panuje w niej klimat, ale też od własnej umiejętności zawiązywania relacji, umiejętności dialogu - umiejętności słuchania innych oraz mówienia tak, aby inni nas wysłuchali.

Marta Michalicka-Ipnarska w artykule pt. Szkota, jakiej potrzebujemy przedstawia szkołę, która działa na innych zasadach. Panuje w niej wzajemne zrozumienie między nauczycielami a uczniami. Nauczyciele rozumieją potrzebę buntu uczniów: „dobrze, że mają się przeciw czemu buntować, gdyż jest to opór, który buduje”. Są świadomi swoich tendencji, wynikających m.in. $z$ odpowiedzialności zawodowej: „mamy tendencję do odgórnego sterowania i podawania gotowych rozwiązań”. Takie uczciwe postrzeganie samych siebie przez nauczycieli jest korzystne dla nich i dla uczniów, gdyż dzięki temu będą dawali uczniom więcej przestrzeni do zadawania pytań, własnych poszukiwań wiedzy i kreowania albo chociaż współkierowania własnym procesem uczenia się. Nauczyciele chcą pracować w takiej szkole, gdyż praca jest dla nich nie tylko rozwojowa w sensie intelektualnym, ale też miła i przyjemna ze względu na dobre relacje: „od początku chciałam w tej szkole pracować, głównie ze względu na ludzi, mają pasje i tryskają energią". W tej szkole dokonuje się dialog między uczniami a nauczycielami i dyrekcją szkoły: „uczniowie w tej szkole wiedzą czego chcą, nie przeraża ich rozmowa $z$ dyrektorem czy wychowawcą, w rozmowie są partnerami"16.

Pozostaje pytanie, jak wiele jest w naszym kraju takich szkół, w których nie ma miejsca na dialog, ze względu na hierarchiczność relacji, anonimowość, problemy osobiste i wiele innych czynników, a ile jest szkól, w których każdy jest partnerem do potencjalnej rozmowy w atmosferze szacunku i zrozumienia. Prawdopodobnie każdy uczestnik życia szkoły życzyłby sobie tej drugiej sytuacji. Jednakże

15 M. Dudzikowa, R. Wawrzyniak-Beszterda, Doświadczenia szkolne pierwszego rocznika reformy edukacji. Studia teoretyczno-empiryczne, Kraków 2010, s. 121.

16 Por. M. Michalicka-Ipnarska, Szkota, jakiej potrzebujemy, dz. cyt., s. 490-492. 
należy pamiętać, że każda osoba ma wpływ na podejmowanie w szkole dialogu lub jego zaniechanie.

Tymczasem pojawia się pytanie o zasady wewnętrznego zorganizowania szkoły jako instytucji. Zarządzanie szkołą niejako domaga się jej wewnętrznej integralności. Skupieniu się na spójnym funkcjonowaniu podmiotów, wchodzących w jej skład, tworzących jej wewnętrzne życie. Nie należy w żaden sposób deprecjonować żadnego z podmiotów uczestniczących w życiu szkoły ${ }^{17}$. Takie poszanowanie jest podstawą do krzewienia dialogu, w tym w polskiej szkole.

\section{Najistotniejsze wskazówki dla nauczycieli, jak ulepszać dialog z uczniami}

Należy pamiętać o tym, jak ważny jest dialog, bowiem jest on jednym z warunków wspomagania prawidłowego rozwoju osobowości uczniów. Kształtowanie osobowości jest jednym z nadrzędnych celów szkoły $^{18}$.

Przede wszystkim należałoby zwrócić uwagę na podmiotowe traktowanie uczniów. Dzieci i młodzi ludzie, tak samo jak dorośli, chcą się uczyć, wiedzieć więcej, współzawodniczyć, ale też współpracować, a nade wszystko pragną podmiotowego - „ludzkiego” traktowania. $\mathrm{Na}$ tym pragnieniu warto budować organizację szkolnej edukacji ${ }^{19}$. Należy realizować zasady personalizacji kształcenia dla wszystkich podmiotów edukacji, w tym także rodziców, dziadków, specjalistów współpracujących ze szkołą i innych ${ }^{20}$. Właśnie w ten sposób przygotowujemy środowisko szkoły, w tym najmłodszych do uczestniczenia w dialogu. Nie ma bowiem mowy o dialogu tam, gdzie nie ma poszanowania godności drugiego człowieka, uwzględnienia jego inności

17 Por. T. Gumuła, T. Dyrda, Wybrane problemy edukacji szkolnej w Polsce, w: Szkoty, nauczyciele, uczniowie. Dyskusja o programie, metodzie, uczeniu sie w Europie, red. T. Gumuła, T. Dyrda, Radom 2009, s. 38.

18 Por. R. Parzęcki, Funkcje pedagogiki w warunkach XXI w., w: Wyzwania wspótczesnej pedagogiki, red. D. Becker-Pestka, E. Kowalik, Warszawa 2015, s. 19-20.

19 Por. J.P. Sawiński, Jak zwiększyć skutecznośc szkolnej edukacji. Poradnik dla edukatorów i nauczycieli, Warszawa 2015, s. 175.

20 Por. tamże, s. 177. 
i niepowtarzalności, z całym bagażem jego doświadczeń, zdolności, pasji, motywacji do nauki oraz różnorodnych braków i problemów.

Janusz Bielski wspomina o istotnych wyznacznikach dialogu z uczniami, do których zalicza umiejętność dostosowania się do odbiorcy, szacunek dla odmiennego zdania ucznia, umiejętność słuchania i empatii, pozytywne nastawienie i akceptacja ucznia, kulturę posługiwania się słowem oraz poczucie humoru nauczyciela ${ }^{21}$. W przypadku dostosowania języka do odbiorcy, autor podkreśla głównie używanie takich słów i sformułowań, które są na dany moment dla ucznia zrozumiałe. Niejednokrotnie wynika to z uproszczenia komunikatu, ale jest to konieczne, żeby uczeń w ogóle mógł pojąć tok myślenia nauczyciela, który stopniowo będzie mógł stosować bardziej wyszukane słowa, pod warunkiem, że będzie tłumaczył uczniowi, co one znaczą. Szacunek dla odmienności człowieka jest przez niego charakteryzowany jako poszanowanie dla odrębności ucznia, unikanie narzucania jemu swoich poglądów, a także umiejętność prowadzenia interesującej i merytorycznej dyskusji prowadzącej do wspólnych wniosków, satysfakcjonujących obie strony. Trzeba pamiętać, że w obecnych czasach mamy do czynienia z pokoleniem wzbraniającym się przed autorytarnym narzucaniem przekonań i opinii. Należy zatem użyć takiej formy dialogu, która uaktywnia umysł ucznia. Chodzi o prawdziwy dialog, o partnerskie, a nie autorytarne komunikowanie się z dziećmi i młodzieżą. Nauczyciel powinien być też otwarty na to, co uczeń ma w rozmowie do zaoferowania. Natomiast zdolność do empatii pozwoli nauczycielowi być wrażliwym na ucznia, rozumieć go i współodczuwać z nim. Pozytywne nastawienie umożliwi nawiązanie relacji pozbawionej uprzedzeń. Kultura posługiwania się słowem oznacza potrzebę odpowiedniej intonacji każdej wypowiedzi nauczyciela, dbanie o dobór słów i jasność wypowiedzi. Ponadto, poczucie humoru pozwoli nauczycielowi na utrzymanie dobrych relacji z uczniami. Uczniowie bardzo lubią takich nauczycieli ${ }^{22}$.

Natomiast Zofia A. Żukowska podkreśla, jak ważny jest kontakt z uczniami, czyli uważne i radosne bycie z nimi w różnych sytuacjach edukacyjnych. Autorka twierdzi, że nie należy blokować naturalnego

21 Por. J. Bielski, Nauczyciel doskonaty. Ksztattowanie sie nauczycielskiego zawodu. Warunki, kryteria i mierniki efektywności pracy nauczyciela, Kraków 2017, s. 57-58.

22 Por. tamże, s. 58. 
kontaktu z uczniami, który powstaje sam przez się. Głównie dzieci, ale też młodzież, instynktownie dążą do kontaktu z dorosłymi, chcą być wysłuchane zauważone, docenione. Zadaniem dorosłych jest te potrzeby zauważyć i starać się zrealizować. Niebranie pod uwagę potrzeb uczniów jest przemocąa ${ }^{23}$.

\section{Metodologiczne podstaw badań własnych}

Przedmiotem niniejszych badań jest dialog w placówkach szkolnych. Celem teoretycznym badań jest ukazanie dialogu w szkole na bazie literatury przedmiotu, a celem praktycznym ukazanie, jak osoby, które pełnią lub będą pełniły funkcję dyrektorów szkót, rozumieją istotę dialogu. Główny problem badawczy brzmi:Jak dyrektorzy szkół postrzegają dialog w placówkach szkolnych? Posłużono się strategią badań jakościowych, metodą dyskusji grupowej, nazywana też m.in. wywiadem zespołowym, która - jak twierdzą Tadeusz Pilch i Teresa Bauman - nie jest zbyt częstą metodą zbierania materiału badawczego w naszym kraju (bardziej popularna m.in. w Niemczech), posiada jednak zalety. Stwarza ona możliwość dostrzeżenia pewnych uwarunkowań społecznych, zachodzących w sytuacjach wychowawczych i dydaktycznych ${ }^{24}$, chociażby związanych z podejmowaniem dialogu w szkołach. Przyjęta została metoda dyskusji grupowej, aby respondenci mogli z łatwością i swobodnie wyrazić swój punkt widzenia, co od badacza wymaga przede wszystkim pogłębionego słuchania, a nie zadawania pytań, w tym takich, na które można odpowiedzieć prosto - „tak”lub „nie”25.

Autorka ma świadomość wycinkowego charakteru niniejszych badań. Interesującym byłoby przeprowadzenie szerszych badań, w tym na większej grupie badawczej.

Por. Z.A. Żukowska, Dialog zamiast kar, Podkowa Leśna 2015, s. 20.

T. Pilch, T. Bauman, Zasady badañ pedagogicznych. Strategie ilościowe i jakościowe, Warszawa 2001, s. 338.

25 D. Kulinowski, Jakościowe badania pedagogiczne. Filozofia. Metodyka. Ewaluacja, Lublin 2010, s. 208. 


\section{Analiza wyników badań własnych}

Analizowane tu badania zostały przeprowadzone $\mathrm{z}$ grupami nauczycieli głównie $z$ województwa małopolskiego, ale także śląskiego i podkarpackiego, uczęszczających na studia podyplomowe z Organizacji i Zarządzania w Oświacie w Akademii Ignatianum w Krakowie, w trzech edycjach, w latach 2015-2018. Objęły one 57 osób. Badani nauczyciele albo pełnili już funkcję wicedyrektora/wicedyrektorki, albo zastępowali czasowo dyrektora szkoły lub byli delegowani przez obecnego dyrektora na studia $z$ organizacji i zarządzania oświatą w celu objęcia tego stanowiska w przyszłości (m.in. po odejściu obecnego dyrektora na emeryturę).

Nauczyciele zapytani, w jaki sposób usprawniają kulturę dialogu w swych placówkach szkolnych, odpowiadali najczęściej, że nie robią nic szczególnego, dialog w szkole i tak się dokonuje, a jego jakość jest dla nich zadowalająca. Sześć osób podjęło próbę dialogu i wskazało indywidualne, interesujące działania, które mogą być inspiracją do dalszej praktyki dialogu w szkołach. Niepokojący jest fakt, że z grupy prawie sześćdziesięciu osób jedynie sześć zabrało głos w niniejszej sprawie i potrafiło określić własne pomysły na dialog w swych placówkach szkolnych.

Niektórzy badani nauczyciele mają świadomość wagi podejmowania dialogu w szkole. Są przekonani, że skuteczna komunikacja jest istotna dla utrzymania pozytywnych relacji, dobrego klimatu szkoły oraz umożliwia właściwy proces wychowawczy uczniów. Ponadto, badani nauczyciele starają się być inicjatorami podejmowania dialogu. Mają świadomość, że to oni powinni zachęcić uczniów i rodziców do autentycznych i otwartych rozmów na różne tematy. Przykładowa wypowiedź:

Prowadzę regularnie rozmowy z rodzicami nie tylko na temat osiągnięć i trudności dotyczących ich dzieci, ale rozmawiamy o wielu innych sprawach, w tym o organizacji klasy, o trudnościach, jakie mają z dziećmi, o radościach, jakie z nimi przeżywają, a nawet o sprawach społecznych. Nie było tak od początku. Za każdym razem, jak przychodziły dzieci do pierwszej klasy, dążyłam do integracji z dziećmi i rodzicami (nauczycielka edukacji wczesnoszkolnej w publicznej szkole podstawowej w Krakowie, z 7-letnim stażem). 
Korzystny wydaje się także fakt, że nauczyciel potrafi zostać zainspirowany do podejmowania dialogu przez innych, w tym m.in. osoby, które mógłby uznać za autorytet:

$\mathrm{Na}$ studiach paru wykładowców, zajmujących się tematyką dialogu, uczulało nas na jego wagę w przedszkolu i szkole. Myślę, że wzięłam sobie to do serca. Faktem jest jednak, że m.in. z powodu głębokiej wiary katolickiej, poszanowanie drugiego człowieka i rozmowa z nim zawsze była dla mnie ważna (nauczycielka edukacji wczesnoszkolnej w publicznej szkole w Krakowie, absolwentka studiów licencjackich i magisterskich Akademii Ignatianum w Krakowie, 3-letni staż pracy po studiach magisterskich).

Badani nauczyciele podkreślają znaczenie nawiązywania dobrych relacji w gronie pedagogicznym, które mają bezpośredni wpływ na relacje z uczniami:

W naszej placówce szkolnej zebrało się takie grono nauczycieli, że bardzo dobrze i łatwo możemy się porozumieć. Każdy z nas jest częścią zespołu i autentycznie wspólnie z dyrekcją decydujemy o kształcie i rozwoju naszej placówki. To daje nam duże poczucie zaangażowania w pracę. Osobiście te partnerskie relacje przenoszę na uczniów. Łatwiej mi się z nimi się porozumieć, mieć cierpliwość i wyrozumiałość, gdyż ja jestem tym obdarzany przez panią dyrektor i moich kolegów z pracy. To jest moja trzecia placówka szkolna, w której pracuję, i w takiej formie dialog odbywa się tylko w niej. $Z$ opowiadań moich kolegów spoza mojej szkoły wiem, że w niektórych placówkach brakuje porozumienia i atmosfera pracy nie jest tak dobra. U nas jest prawie wzorcowa (nauczyciel historii w publicznej szkole ponadgimnazjalnej, 25-letni staż pracy).

Należy podkreślić, że dla niektórych respondentów istotnym elementem integrującym ich z uczniami i rodzicami jest posiadana przez nich pasja, którą starają się dzielić i której wspólne realizowanie staje się pretekstem do podejmowania dialogu:

Moją pasją jest taniec i stwierdziłam, że organizowanie wspólnych imprez tanecznych dla dzieci i rodziców w szkole raz w miesiącu będzie najlepszym sposobem na zawiązanie więzi. Taniec wyzwala pozytywne emocje, człowiek w tańcu jest prawdziwy, nie udaje. Moim zdaniem taniec zbliża ludzi i warto się na tym polu spotykać. Na początku rodzice są zdziwieni propozycją i w większości niechętni, ale jak widzą, że się nie zrażam, to podejmują wyzwanie. W trakcie jest przy tym dużo radości i śmiechu. Dołączyłam w repertuar imprez wspólne zabawy i zawody, w tym z nagrodami. Moja otwartość oraz chęć rozmowy oraz wspólnych działań, w których sama dobrze się czuję, przyczyniają się do utrzymania 
dobrych relacji z rodzicami (nauczycielka edukacji wczesnoszkolnej w publicznej szkole podstawowej w Krakowie, z 7-letnim stażem).

Inna wypowiedź, świadcząca o interesującym wykorzystaniu swojej pasji:

Jestem polonistką z zamiłowania. Od zawsze wiedziałam, gdzie chcę studiować i pracować. Czytanie, ale też pisanie, w moim przypadku jest sposobem na życie. Poprzez literaturę, m.in. przykłady postaci zaczerpnięte z powieści, baśni itp. ukazuję uczniom dobre i złe przykłady, uczę norm i wartości. Uważam, że w liceum uczniowie są na tyle dorośli, że mogą wybierać literaturę sami. Coraz częściej polecają mnie i klasie jakieś pozycje książkowe, które czytam, żeby móc z nimi o nich rozmawiać. Sprawia nam to obopólną wielka radość. Cieszę się, że samodzielnie, bez przymusu, dla relaksu sięgają po książki. Oni natomiast czują się ważni, że mogą podsunąć jakąś książkę nauczycielowi i on ją przeczyta, a nawet będzie o tym dyskusja. Mogą też decydować, na jak spektakl idziemy, co zajmuje więcej czasu i zawsze jest ktoś, kto chciałby obejrzeć coś innego, ale w ogólnym rozrachunku wszyscy są zadowoleni. Rozmawiamy, idziemy na kompromis, szanujemy gusta poszczególnych osób. Czuję, że są partnerami do rozmowy. $\mathrm{Na}$ lekcjach nigdy nie ma nudy, jest ciekawie i dynamicznie. Bardzo lubię z nimi pracować. W szkole publicznej, w której pracowałam na początku swojej kariery, niestety nie udało mi się takiej dobrej atmosfery wypracować. Uczniowie byli niechętni, wszyscy traktowali się dość anonimowo, a pewnie i ja nie miałam aż takiej odwagi i doświadczenia, żeby nauczać po swojemu w duchu dialogu (nauczycielka języka polskiego w ponadgimnazjalnej szkole społecznej, z 20-letnim stażem).

Ponadto, badani nauczyciele ukazują również efekt ich działań związanych z podejmowaniem dialogu, podkreślając uzyskiwanie wzajemnego zrozumienie i wsparcie, a także wspólne istotne działania:

Rodzice nie mają oporów, żeby zapytać o radę, jak jej potrzebują, ale i ja chętnie korzystam $\mathrm{z}$ relacji rodzicielskich, jakie dziecko jest $\mathrm{w}$ domu, gdyż pomaga to utrzymać ciąłość w wychowaniu między szkołą a domem. Czuję od rodziców akceptację, wsparcie i wdzięczność. Niestety po trzech pierwszych latach musiałam zmienić szkołę, gdyż dyrekcja (także niektóre starsze stażem koleżanki) nie akceptowała mojego stylu utrzymywania bliższych kontaktów z rodzicami i miałam z tego powodu powtarzające się z nią rozmowy. Sugerowała bardziej „przemyślany i profesjonalny” styl prowadzenia klasy. W obecnej szkole mój pomysł na integrację i dialog jest akceptowany, nawet podziwiany. Ośmieliłam też moje koleżanki do podobnych działań (nauczycielka edukacji wczesnoszkolnej w publicznej szkole podstawowej w Krakowie, z 7-letnim stażem). 
Nauczyciele podają też przykłady dobrych zagranicznych praktyk w zakresie nawiązywania dialogu:

Ponadto, na zajęciach z pedagogiki porównawczej dowiedziałam się więcej o edukacji w Wielkiej Brytanii, w tym przede wszystkim o tym, że kultywuje się w tamtejszych szkołach dialog z uczniami, nie tylko $\mathrm{w}$ ramach m.in. godziny wychowawczej - jak to jest w naszym kraju, czy jak uczeń ma już jakieś konkretne problemy, ale częściej, w ramach konkretnego przedmiotu, także zawsze, gdy jest taka potrzeba i jest trochę wolnego czasu (nauczycielka edukacji wczesnoszkolnej w publicznej szkole w Krakowie, absolwentka studiów licencjackich i magisterskich Akademii Ignatianum w Krakowie, 3-letni staż pracy po studiach magisterskich).

\section{Kolejna wypowiedź na ten temat:}

Przypomina mi się przykład fiński - praca i nauka bez stresu, a jednak bardzo efektywnie (nauczyciel historii w publicznej szkole ponadgimnazjalnej, 25-letni staż pracy).

Nauczyciel ten nadmienit, że zna fiński system edukacji, w tym fińską kulturę uprawiania dialogu, nie tylko z literatury przedmiotu, ale $\mathrm{z}$ licznych wyjazdów w zakresie wymiany międzyszkolnej.

Niektórzy badani nauczyciele, jak w przypadku nauczycielki edukacji wczesnoszkolnej, wykorzystują swą wiedzę w praktyce edukacyjnej:

Wzorem brytyjskim codziennie zbieram dzieci w kółku na dywanie, rozkładamy różne karty obrazkowe, które, co istotne, zrobiliśmy wspólnie z dziećmi, i które są pomocne w określaniu ich stanów emocjonalnych. Dzieci wybierają karty i mówią, jak się czują i dlaczego. Mają dowolność wzięcia udziału w zabawie lub jego zaniechanie, ale często większość $\mathrm{z}$ nich ma ochotę opowiedzieć o tym, co przeżywają. Omawiamy w kole także różne inne sprawy związane z klasą. Ta metoda sprawdza się znakomicie. Wiem, że uczę je, jak słuchać siebie i jak prowadzić dialog z innymi (nauczycielka edukacji wczesnoszkolnej w publicznej szkole w Krakowie, absolwentka studiów licencjackich i magisterskich Akademii Ignatianum w Krakowie, 3-letni staż pracy po studiach magisterskich).

Jedna $\mathrm{z}$ nauczycielek akcentuje $\mathrm{z}$ kolei istotę zadawania pytań jako pewne "narzędzie" podejmowania dialogu, ale też w szerszym kontekście jako ideę:

Staram się wpajać moim uczniom, żeby nie bali się zadawać pytań dorosłym również. Uważam bowiem, że jest to bardzo ważny czynnik dialogu i, jak się okazuje, czasem trudna umiejętność. Po to, aby mądrze zadać 
pytanie, trzeba dokładnie słuchać, prawidłowo rozumować, a nawet mieć już jakąś uprzednią wiedzę na ten temat. Uczniowie nie są przyzwyczajeni do zadawania pytań. Pamiętam swoje własne dzieci (dwójkę) w wieku zanim poszły do szkoły, stale o coś mnie z mężem pytali. Jak poszli do szkoły, to pytania zanikły. Zaczęliśmy się nawet zastanawiać i martwić, dlaczego tak się stało. Doszliśmy do wniosku, że raczej nie mogą sobie pozwolić na zadawanie pytań w klasie szkolnej. Jest to może nawet poniekąd zrozumiałe, że nauczyciel może myśleć, że nie ma czasu przy tak dużej grupie. Można sobie wyobrazić, jak wyglądałaby lekcja, jakby każdy uczeń chciał zadać choć jedno pytanie do zagadnienia. Jednak uważam, że można poświęcić jakiś czas na naukę zadawania pytań. Osobiście nie boję się, że na jakieś nie będę znała odpowiedzi i stracę przez to autorytet uczniów. Uczę ich, że jeśli czegoś nie wiemy, będziemy razem poszukiwać odpowiedzi i że każdy może mieć inne zdanie na dany temat. Ta metoda skutkuje w mojej pracy. Cieszę się też, że mogłam wysłuchać, jak moi koledzy ze studiów radzą sobie z dialogiem uczniami, może coś uda mi się wdrożyć (nauczycielka wygaszanego obecnie gimnazjum w Rzeszowie, 12-letni staż pracy).

Natomiast jedna z nauczycielek wskazała, jak ważna jest wzajemna otwartość w nawiązywaniu dialogu:

$\mathrm{Z}$ niedowierzaniem słucham pozytywnych wypowiedzi moich przedmówców na temat pozytywnych aspektów dialogu w ich placówkach. W naszej placówce jest zupełnie inaczej. Najtrudniejszy dialog jest nie tylko z dziećmi, które z powodu swoich niepełnosprawności mogą czegoś nie rozumieć, ale $\mathrm{z}$ ich rodzicami. Jest to $\mathrm{w}$ większości środowisko patologiczne. Nie jesteśmy w stanie przeforsować nawet najprostszych wartości i zasad, dla ich dobra i dobra ich dzieci. Oni tego zupełnie nie przyjmują. Osobiście nie podejmuję już zbyt wielu rozmów. Zauważyłam, że bardzo ograniczyłam kontakty z rodzicami, ze względu na ochronę swojego samopoczucia i zdrowie. Nie mam siły już z nimi „walczyć” nawet o najprostsze wyposażenie dziecka w niezbędne przybory. Radzimy sobie sami. Jak któryś uczeń czegoś nie ma, to inni mu pożyczają. Nie widzę możliwości zmiany w tej placówce. Myślę, że wypaliłam się w niej. Podnoszę swoje kwalifikacje, żeby znaleźć inną pracę. Brak partnerów do rozmowy (nauczycielka szkoły specjalnej w Krakowie, 30-letni staż).

\section{Podsumowanie i wnioski dla dalszej praktyki edukacyjnej}

Badane osoby podejmowały dialog z młodzieżą na bazie własnych pasji, które w niektórych przypadkach dotyczyły nauczanych przez nich przedmiotów. Prawdopodobnie był to sposób na znalezienie wspólnego języka z uczniami, ale także z rodzicami. „Bycie w stanie”, 
w języku angielskim określanym jako a flow czyli przepływ, płynność, lekkość, pozwalało im na bycie radosnym i autentycznym. To z kolei pociągało za sobą kreowanie takiej atmosfery w klasie, żeby także uczniowie czuli się bardzo dobrze i chętnie rozmawiali z nauczycielami na różne tematy.

Mimo że osoby badane należą, m.in. z racji odbywanych studiów, do grupy tych, które będą w przyszłości sprawowały funkcje dyrektorów poszczególnych szkół, nie przedstawiły one podczas wywiadu żadnych kompleksowych pomysłów dla wszystkich podmiotów edukacji, w tym rodziców, usprawniających dialog między nimi. Nie sugerowały również, że takie koncepcje posiadają. Żaden uczestnik wywiadu nawet nie wspomniał, że w ogóle chciałby w przyszłości stworzyć jakiś plan dotyczący wdrażania umiejętności dialogu w placówce szkolnej. Przedstawione przez badanych pomysły nie były zbytnio obszerne, aczkolwiek z tego co relacjonowali - skuteczne.

Widoczna jest wśród osób, które podawały interesujące pomysły na podtrzymywanie dialogu, świadomość jego konieczności. Może to skutkować poszukiwaniami systemowych i efektywnych rozwiązań w przyszłości, gdy już będą pełniły funkcję dyrektora szkoły.

Wszyscy zgodnie podkreślali istotę dobrej atmosfery w szkole, która z jednej strony jest wynikiem podejmowania rozmów i wzajemnego zrozumienia, a $z$ drugiej ułatwia dialog. Pomiędzy tymi dwoma zmiennymi występuje sprzężenie zwrotne.

Ponadto, niektóre środowiska szkolne są tak trudne i niereformowalne, że mimo usilnych starań nauczycieli i dyrekcji szkoły dialog nie następuje. Jest to bardzo deprymujące dla nauczycieli, którzy w końcu godzą się z porażką i albo zachowują bierną postawę, albo zaczynają się rozglądać za przeniesieniem do bardziej podatnego na dialog środowiska szkolnego.

Sugeruje się zatem, żeby nauczyciele stale poszerzali swoje kompetencje komunikacyjne w całej ich karierze zawodowej, w ramach warsztatów oraz własnych studiów literatury. Umiejętności te są bowiem kluczowe w procesie edukacyjnym.

- W placówkach szkolnych powinno się zwrócić baczniejszą uwagę na wypracowanie konkretnych strategii służących poprawie lub/i utrzymanie w dobrej formie dialogu między wszystkimi uczestnikami procesu edukacyjnego. Plan taki wymaga zaangażowania całej rady pedagogicznej. Powinien być 
sporządzany na piśmie, regularnie udoskonalany co najmniej raz w roku, lub częściej. Wskazana byłaby też ewaluacja procesu wdrażania niniejszego planu.

- Korzystnym byłoby obranie w placówce szkolnej jakiegoś podejścia nawołującego do dialogu, porozumienia bez przemocy, zachowania postawy empatii itp. Byłby on wzorem i punktem oparcia dla podtrzymywania dialogu w szkole. Jego opracowanie mogłoby odbyć się z udziałem pracowników naukowych, których można zaprosić do współpracy szkolnej.

- Dobrze byłoby, gdyby nauczyciele dbali o swój rozwój osobowy, w znaczeniu znajomości własnych emocji, konsekwencji działań, umiejętności radzenia sobie z emocjami, w tym $\mathrm{z}$ frustracją, która może pojawiać się w przypadku natłoku zajęć czy braku osiągnięć szkolnych niektórych uczniów. Nauczyciel, którego cechuje przepracowanie, którego dotyka stres i obawa o zachowanie posady, wypalenie zawodowe i inne tego typu problemy, nie będzie miał ochoty wchodzić w dialog z uczniami. Będzie prezentował niewłaściwe postawy, w tym agresji lub wycofania $z$ relacji.

- Warto byłoby organizować publiczne bezpłatne warsztaty nauki dialogu dla obywateli. Prawdopodobnie niektórzy rodzice skorzystaliby z tej oferty, a nauczycielom byłoby łatwiej się z nimi porozumieć.

- W ramach studiów, nie tylko pedagogicznych, psychologicznych czy socjologicznych powinien występować kurs w postaci jednego przedmiotu (kilku przedmiotów, lub jako ścieżka międzyprzedmiotowa), w ramach którego studenci mogliby nabyć nie tylko teoretycznych, ale - co istotne - praktycznych umiejętności dialogowania.

- Należałoby się zastanowić, czy nie warto jednak dostosować swojego języka wypowiedzi do rozmówcy, m.in. przypadku osób ze środowisk defaworyzowanych, w celu nawiązania kontaktu z nimi i stopniowego uczenia ich dialogu na wyższym poziomie językowym.

- Należałoby wziąć pod uwagę fakt narastającej fali przybyszów z innych krajów, których dzieci są już w szkole lub za niedługo zaczną do niej chodzić. Trzeba wypracować pewien konsensus między otwartością wobec nich a wymaganiami asymilacji. 
Nie mogą oni z jednej strony czuć się odrzuceni z powodu swojej inności, ale też ich znacznie odmienne zachowania, przyzwyczajenia itp. nie powinny zaburzać procesu edukacyjnego. Taka sprawiedliwa sytuacja pomoże w podejmowaniu dialogu. Pozostaje także kwestia języka, który niejednokrotnie jest dość dużą barierą. Autorka z własnych doświadczeń pracy w obcym kraju zauważyła, że poznanie i stosowanie przez nauczycieli chociaż paru słów, pojęć w narodowym języku dziecka przekonuje je do niego, gdyż czuje się ono akceptowane, i zachęca do nauki języka kraju przyjmującego.

\section{Bibliografia}

Bielski J., Nauczyciel doskonaty, Ksztattowanie sie nauczycielskiego zawodu, warunki, kryteria i mierniki efektywności pracy nauczyciela, Oficyna $\mathrm{Wy}_{\mathrm{-}}$ dawnicza „Impuls”, Kraków 2017.

Chodorowska-Chromiec M., Kompetencje komunikacyjne nauczyciela w pracy z uczniem, w: Nauczyciel kompetentny. Teraźniejszośc i przysztośc, red. Z. Bartkowicz, M. Kowalczuk, M. Samujło, Wydawnictwo UMCS, Lublin 2007, s 139-146.

Dudzikowa M., Wawrzyniak-Beszterda R., Doświadczenia szkolne pierwszego rocznika reformy edukacji. Studia teoretyczno-empiryczne, Oficyna Wydawnicza „Impuls”, Kraków 2010.

Feinberg W., Solis J., Szkoła i spoteczeństwo, przeł. K. Kruszewski, WSiP, Warszawa 2000.

Giroux H.A., McLaren P., Ameryka 2000 i polityka wymazywania, Demokracja i różnice kulturowe w oblężeniu, w: Nieobecne dyskursy, cz. 3, red. Z. Kwiecińska, Wydawnictwo Uniwersytetu Mikołaja Kopernika, Toruń 1993, s. 77-94.

Gumuła T., Dyrda T., Wybrane problemy edukacji szkolnej w Polsce, w: Szkoty, nauczyciele, uczniowie. Dyskusja o programie, metodzie, uczenia się w Europie, red. T. Gumuła, T. Dyrda, Wydawnictwo Naukowe Instytutu Technologii Eksploatacji - PIB, Radom 2009.

Habermas J., Teoria dziatania komunikacyjnego. Racjonalnośc dziatania a racjonalnośćspoteczna, t. 1, przeł. A.M. Kaniowski, Wydawnictwo Naukowe PWN, Warszawa 1999.

Kubinowski D., Jakościowe badania pedagogiczne. Filozofia. Metodyka. Ewaluacja, Wydawnictwo UMCS, Lublin 2010.

Matusz-Rżewska A., Nauczyciel-uczeń. O paradoksach wzajemnej komunikacji, w: Ucztowieczyć komunikacje. Nauczyciel wobec ucznia w przestrzeni 
szkolnej, red. H. Kwiatkowska, Oficyna Wydawnicza „Impuls”, Kraków 2015, s. 461-480.

McLaren P.L., Antystruktura oporu, w: Nieobecne dyskursy, cz. 2, Wydawnictwo UMK, Torun 1992, s. 31-53.

Michalicka-Ipnarska M., Szkota, jakiej potrzebujemy, w: Uczłowieczyć komunikacje. Nauczyciel wobec ucznia w przestrzeni szkolnej, red. H. Kwiatkowska, Oficyna Wydawnicza „Impuls”, Kraków 2015, s. 482-498.

Parzęcki R., Funkcje pedagogiki w warunkach XXI w., w: Wyzwania wspótczesnej pedagogiki, red. D. Becker-Pestka, E. Kowalik, Wydawnictwo Wyższej Szkoły Bankowej w Gdańsku, Warszawa 2015, s. 13-24.

Pilch T., Bauman T., Zasady badań pedagogicznych. Strategie ilościowe i jakościowe, Wydawnictwo Akademickie „Żak”, Warszawa 2001.

Retter H., Komunikacja codzienna w pedagogice, przeł. M. Wojdak-Piątkowska, Gdańskie Wydawnictwo Psychologiczne, Gdańsk 2005.

Samujło M., Sokołowska-Dzioba T., Jezzyk otwartości w relacji nauczyciel-uczeń, w: Uczłowieczyć komunikacje. Nauczyciel wobec ucznia w przestrzeni szkolnej, red. H. Kwiatkowska, Oficyna Wydawnicza „Impuls”, Kraków 2015, s. 440-453.

Sawiński J.P., Jak zwiększyć skuteczność szkolnej edukacji. Poradnik dla edukatorów i nauczycieli, Difin, Warszawa 2015.

Śliwiński P.J., Zagubiony i odnaleziony w nie-miejscu, w: Kondycja cztowieka wspótczesnego, red. C. Piecuch, Universitas, Kraków 2006, s. 150-178.

Śnieżyński M., Sztuka dialogu. Teoretyczne zatożenia a szkolna rzeczywistość, Wydawnictwo Naukowe AP, Kraków 2005.

Śnieżyński M., Zarys dydaktyki i dialogu, Wydawnictwo PAT, Kraków 1998. Ustawa o systemie oświaty z dnia 14 grudnia 2016 r., Rozdz. 1, art. 1, pkt. 1, 3, 5, 8, 18 (tekst jednolity: Dz. U. 2017 poz. 59, z późn. zm.).

Zukowska Z.A., Dialog zamiast kar, Wydawnictwo MiND, Podkowa Leśna 2015.

\title{
ADRES DO KORESPONDENCJI
}

\author{
Dr Aneta Kamińska
}

Akademia Ignatianum w Krakowie

Wydział Pedagogiczny

Instytut Nauk o Wychowaniu

e-mail: aneta.kaminska@ignatianum.edu.pl 